\title{
Praktek Relationship Marketing dalam Menciptakan Loyalitas pada Perbankan Syariah Indonesia: Systematic Literature Review
}

\author{
Fatimatul Fatmariyah'1, Iskandar Ritonga², Luluk Latifah ${ }^{3}$, Fathor AS \\ 1 Universitas Islam Negeri Sunan Ampel Surabaya \\ 2 Universitas Islam Negeri Sunan Ampel Surabaya \\ 3 Universitas Islam Negeri Sunan Ampel Surabaya \\ 4 Universitas Trunjoyo Madura Bangkalan
}

\begin{tabular}{|c|c|}
\hline ARTICLE INFO & Abstract \\
\hline $\begin{array}{l}\text { Article History: } \\
\text { Accepted : Desember } 2021 \\
\text { Fixed : Desember } 2021 \\
\text { Approved: Desember } 2021\end{array}$ & \multirow{2}{*}{$\begin{array}{l}\text { The population of Indonesia is mostly Muslim, but the market share of } \\
\text { Indonesian Islamic banking is very small at 6.51\%, this condition is further } \\
\text { strengthened by the weak practice of relationship marketing in Indonesian } \\
\text { Islamic banks. The purpose of this study is to identify and analyze the } \\
\text { empirical literature of the last } 10 \text { years (2010-2020) related to relationship } \\
\text { marketing practices in Indonesian Islamic banking. This research method is } \\
\text { Systematic Literature Review which is done through literature search on } \\
\text { Google Scholar, Garuda Portal and Google. The population is 74,177 titles and } \\
\text { the sample is } 11 \text { titles. SLR is carried out through } 3 \text { stages: planning, } \\
\text { implementing and reporting the literature review. The results of the study } \\
\text { show that the method used is quantitative, Indonesian Islamic banking has } \\
\text { implemented relationship marketing, relationship marketing practices create } \\
\text { loyalty, Islamic banking relationship marketing practices are still low, and the } \\
\text { solution for Islamic banks is to increase the application of relationship } \\
\text { marketing indicators, education, socialization and the ability of officers. . The } \\
\text { implications of this study provide benefits for developing relationship } \\
\text { marketing theory in Islamic banking and finding new strategic references that } \\
\text { need to be developed by Indonesian Islamic banking. }\end{array}$} \\
\hline $\begin{array}{l}\text { Keywords: } \\
\text { Islamic Banking; Loy } \\
\text { Relationship Marketing. }\end{array}$ & \\
\hline & Abstraks \\
\hline $\begin{array}{l}\text { Kata Kunci: } \\
\text { Bank Syariah; } \\
\text { Pemasaran Relasional. }\end{array}$ & \multirow{2}{*}{$\begin{array}{l}\text { Penduduk Indonesia sebagian besar beragama Islam, tetapi market } \\
\text { share perbankan syariah Indonesia sangat kecil 6,51\%, kondisi tersebut } \\
\text { semakin diperkuat dengan lemahnya praktek relationship marketing di } \\
\text { bank syariah Indonesia. Tujuan studi ini untuk mengidentifikasi dan } \\
\text { menganalisis literatur empiris } 10 \text { tahun terakhir (2010-2020) terkait } \\
\text { praktek relationship marketing pada perbankan syariah Indonesia. } \\
\text { Metode penelitian ini adalah Systematic Literature Review/SLR yang } \\
\text { dilakukan melalui penelusuran literatur pada Google Cendekia, Portal } \\
\text { Garuda dan Google. Populasi } 74.177 \text { judul dan sampel } 11 \text { judul. SLR } \\
\text { dilakukan melalui } 3 \text { tahap : perencanaan, pelaksanaan dan pelaporan } \\
\text { tinjauan literatur. Hasil studi menunjukkan bahwa metode yang } \\
\text { digunakan adalah kuantitatif, perbankan syariah Indonesia telah } \\
\text { mengimplementasikan relationship marketing, praktek relationship } \\
\text { marketing menciptakan loyalitas, praktek relationship marketing } \\
\text { perbankan syariah masih rendah, dan solusi bagi bank syariah adalah } \\
\text { meningkatkan penerapan indikator relationship marketing, edukasi, }\end{array}$} \\
\hline DOI: & \\
\hline
\end{tabular}




\begin{tabular}{|l|l|l|}
\hline & $\begin{array}{l}\text { Sosialisasi dan kemampuan petugas. Implikasi studi ini memberikan } \\
\text { benefit pengembangan teori relationship marketing pada perbankan } \\
\text { syariah dan menemukan referensi strategibaru yang perlu } \\
\text { dikembangkan perbankan syariah Indonesia. }\end{array}$ \\
\hline $\begin{array}{l}\text { Correspondence: } \\
\text { Name: Fathor AS }\end{array}$ & ISSN: 2355-9543 (Print) \\
Email: fathor.as.trunojoyo@gmail.com & ISSN: 2460-3775 (Online) \\
\hline
\end{tabular}

\section{INTRODUCTION}

Tahun 2020 fungsi intermediasi perbankan syariah berjalan dengan baik. Pembiayaan yang diberikan dan dana pihak ketiga masing-masing tumbuh positif sebesar $8,08 \%$, dan $11,98 \%$, sehingga pertumbuhan aset perbankan syariah selama periode tersebut sebesar $13,11 \%$ pada akhir tahun 2020. Akan tetapi jika di bandingkan dengan 5 tahun sebelumnya, ini mengalami penurunan. Dari sisi asset tahun 2016 sebesar 20,28\% dan tahun 2020 sebesar 13,11\% dari sisi PYD tahun 2016 sebesar $16,41 \%$ dan tahun 2020 sebesar 8,08\%, sedang dari sisi dana pihak ketiga (DPK) mengalami penurunan data dari tahun 2016 sebesar 20,84\% dan menurun di tahun 2020 menjadi 11,98\%.(OJK, 2020).

Adanya kecendrungan pertumbuhan pada tahun 2020 tidak terlepas dari market share yang terus meningkat dan menunjukkan bahwa layanan perbankan syariah makin dipercaya oleh masyarakat terutama pada masa pandemic covid19. Namun dalam laporan (OJK, 2020) tercantum bahwa market share perbankan syariah masih sangat kecil yaitu 6,51\% yang terbagi 65,21\% BUS, 32,33 UUS dan 2,46\% BPRS, walaupun Indonesia sebagian besar penduduknya beragama Islam.

Artinya bahwa masih perlu kerja keras dari perbankan syariah untuk dapat menguasai market share yang lebih besar. Hal ini mengingat dalam pokok-pokok hasil penelitian Bank Indonesia pada tahun sebelumnya menyatakan bahwa nasabah yang menggunakan jasa lembaga keuangan shariah, sebagian memiliki kecenderungan untuk berhenti menjadi nasabah, dengan alasan karena adanya keraguan akan konsistensi penerapan prinsip shariah. Hal tersebut menunjukkan bahwa praktik lembaga keuangan shariah selama ini kurang memperhatikan prinsip-prinsip shariah, baik dalam customer value maupun keunggulan produk shariahnya. (Wardayati, 2011).

Oleh karena itu, praktek relationship marketing menjadi salah satu solusi bagi perbankan syariah dalam mengoptimalkan kinerja yang akan membawa implikasi yang lebih baik terhadap hubungan jangka panjangdengan konsumen, karena saat ini yang terjadi menurut Shetty and Basri adalah there is a lack of attention given to the theoretical relationship marketing in banking and insurance service.(Harun, Noor and Ramasamy, 2019). Sehingga the significance of relationship marketing has been acknowledged and recommended as a strategy to overcome service intangibility. (Harun, Noor and Rahman, 2018). Sejatinya relationship marketing merupakan suatu strategi, proses dan aktivitas untuk menciptakan, membangun, menarik, memelihara, mempertahankan, layanan multi dan meningkatkan hubungan-hubungan yang kuat dengan pelanggan dan stakeholder lainnya yang dapat dicapai dengan saling tukar dan pemenuhan janji-janji.(Grönroos, 1994; Sin et al., 2005; Tjiptono, 2011).

Menciptakan, membangun, menarik, memelihara dan mempertahankankonsumen memang suatu pekerjaan yang sangat berat, karena konsumen saat ini berada dalam posisi sebagai pembeli yang irrasional/emosional dimana emotional quotient lebih unggul dari intelligent quotient, dan keungggulan bersaing perusahaan lebih banyak ditentukan oleh feel benefit, sehingga pemasar perlu untuk memahami tentang relationship marketing karena konsumen lebih menyukai relationship yang akan dapat meningkatkan share of wallet dari pelanggan. (Kartajaya, dkk, 2003).

Saat ini, penerapan relationship marketing menjadi keharusan bagi perbankan syariah. Strategi ini menjadi sangat penting sebagai upaya dalam melakukan hubungan dengan nasabah dan mengembangkan loyalitas nasabah jangka panjang, mengingat semakin besarnya ekspektasi masyarakat terhadap eksistensi lembaga keuangan yang konsisten terhadap shariah compliance.

Penerapan relationship marketing yang efektif akan memberikan beberapa manfaat 1). Manfaat Ekonomis, 2). Manfaat Sosial dan 3). Ikatan Struktural. (Kotler, 2010).Dalam penerapannya, banyak dimensi relationship marketingyang digunakan dalam prakteknya antara lain yaitu : Bonding, Empathy, Reciprocity, Trust, Commitment, Shared Value, Communication, Conflict Handling, 
Praktek Relationship Marketing dalam Menciptakan Loyalitas...

Fatimatul Fatmariyah, IskandarRitonga, Luluk Lathifah, Fathor AS

Responsiveness, Belonging, Customization, Differentiation, Personalization, Rewarding, Security, Convenience, Gratitude, Equity, Kompetensi, CoOperation, Power, Non-Opportunistic Behavior, Interdependence dan Timbal Balik. (Sin et al., 2005; Kotler, 2010; Saputra, 2014; Rahmawaty, 2015; Suparwata, 2017).

Lebih jauh, relationship marketingyang berupaya menjalin hubungan jangka panjang dengan para pelanggan, dimana terdapat hubungan yang kokoh dan saling menguntungkan antara penyedia jasa dan pelanggan yang dapat membangun transaksi ulangan dan menciptakan loyalitas pelanggan. (Saputra, 2014). Dalam praktek relationship marketing di perbankan syariah saat ini masih ditemukan adanya gap secara empiris, hal ini tampak dari beberapa dimensi relationship marketing seperti social benefit dan structural benefit berpengaruh negatif terhadap loyalitas nasabah serta secara analitis bahwa hanya $40,3 \%$ saja yang bisa di jelaskan pengaruh financial benefit, social benefit dan structural benefit terhdap loyalitas nasabah, dengan demikian perbankan syariah harus dapat menggali lebih dalam faktor-faktor lain yang dapat meningkatkan loyalitas nasabah, karena masih ada 59,7\% lagi yang tidak terungkap dalam penelitian ini. (Yusriadi, 2017). Selain itu, kepercayaan, komitmen, komunikasi dan penanganan konflik berpengaruh signifikan terhadap retensi nasabah. (Diantara and Samsir, 2015).

Fakta mengungkapkan bahwa pertumbuhan nasabah bank syariah di Indonesia masih rendah. Rendahnya pertumbuhan nasabah bank syariah dikarenakan lemahnya loyalitas nasabah bank syariah, hanya $33,75 \%$ saja nasabah bank syariah yang loyal dalam bentuk kesediaan nasabah untuk melakukan pembelian ulang dan merekomendasikan bank syariah kepada pihak lain. Salah satu yang menjadi faktor penting dari loyalitas nasabah adalah kepuasan. Apabila nasabah merasa puas, maka nasabah tidak akan segan merekomendasikan untuk mengjak orang lain turut serta menjadi nasabah bank tersebut (Ifham 2008, Hafasnuddin 2007 dalam (Arwani, 2011).

Sehingga tujuan dari Systematic Literature Review (LSR) ini adalah untuk mengidentifikasi dan menganalisis literatur empiris 10 tahun terakhir (2010-2020) terkait praktek relationship marketing pada perbankan syariah di Indonesia yang terkait loyalitas. Melalui tinjauan sistematis ini, temuan para peneliti terdahulu akan dapat diperjelas sehingga dapat menemukan strategibaru yang dibutuhkan oleh perbankan syariah di Indonesia. Kontribusi lainnya adalah pentingnya dimensi dari relationship marketing pada perbankan syariah, akan membantu perkembangan perbankan syariah di Indonesia.

\section{METHOD}

Jenis penelitian ini merupakan penelitian deskriptif dengan menggunakan metode Systematic Literature Review/Review Artikel Terstruktur. Systematic Literature Review didefinisikan sebagai proses mengidentifikasi, menilai, dan menafsirkan semua bukti penelitian yang tersedia dengan tujuan untuk memberikan jawaban untuk pertanyaan penelitian tertentu (Kitchenham and Charters dalam (Latifah dan Ritonga, 2020).

Metode Review ini dilakukan melalui penelusuran literatur yang berasal dari database Google Cendekia, Portal Garuda dan Google. Populasi data penelitian adalah jurnal dengan fokus relationship marketing dan loyalitas atau padanannya pada perbankan syariah di Indonesia sebanyak 74.177 judul/artikel dan yang sesuai dengan topik penelitian sebanyak 61 judul serta yang cocok sebagai sampel adalah 11 judul/artikel.

Systematic Literature Review dalam penelitian ini dilakukan melalui tiga tahapyaitu : perencanaan, pelaksanaan dan pelaporan tinjauan literatur. 
Skema 1. Langkah-Langkah Systematic Literature Review

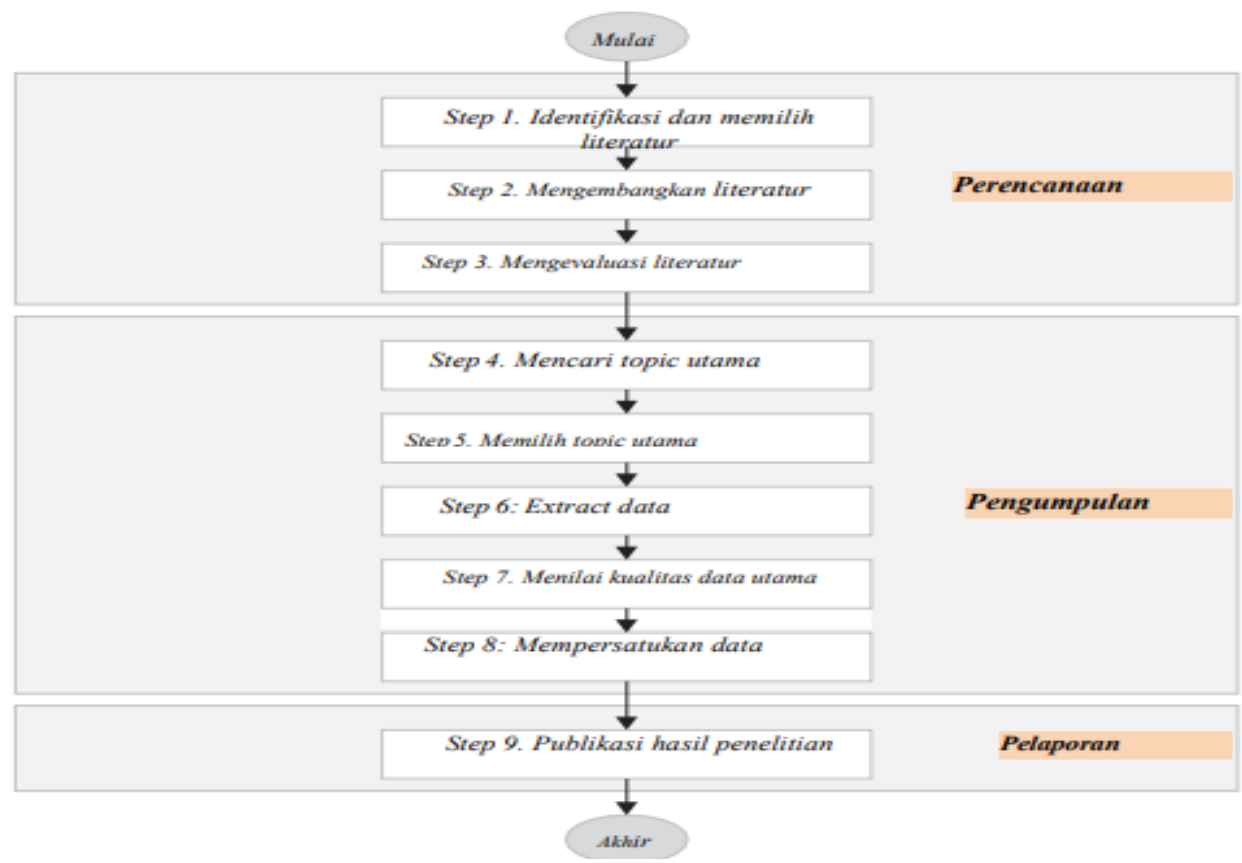

Penelitian pendekatan SLR dipandu dengan pertanyaan penelitian. Research Question (RQ) dibuat agar systematic review yang dilakukan dalam penelitian tetap fokus. Research question disusun dengan bantuan kriteria PICOC yaitu
Population/Populasi, Intervention/Intervensi, Comparison/Perbandingan, Outcomes/Hasil dan Context/Konteks. (Kitchenham and Charters dalam (Latifah dan Ritonga, 2020).

Tabel 1. Ringkasan PICOC

\begin{tabular}{|l|l|}
\hline Population & $\begin{array}{l}\text { Relationship marketing dan loyalitas atau padanannya, praktek relationship } \\
\text { marketing dalam menciptakan loyalitas di perbankan syariah }\end{array}$ \\
\hline Intervention & $\begin{array}{l}\text { Rendahnya praktek relationship marketing dalam menciptakan loyalitas di } \\
\text { perbankan syariah }\end{array}$ \\
\hline Comparison & n/a \\
\hline Outcomes & $\begin{array}{l}\text { Faktor utama relationship marketing dalam menciptakan loyalitas di perbankan } \\
\text { syariah }\end{array}$ \\
\hline Context & $\begin{array}{l}\text { Kerjasama antar lembaga antara akademisi, pembuat keputusan, dan lembaga } \\
\text { perbankan syariah }\end{array}$ \\
\hline
\end{tabular}

Research question yang dibangun pada penelitian ini seperti tertera pada tabel 2 dibawah:

Tabel 2.Research Question (RQ)

\begin{tabular}{|c|l|l|}
\hline RQ & \multicolumn{1}{|c|}{ Research Question } & \multicolumn{1}{c|}{ Motivation } \\
\hline RQ1 & $\begin{array}{l}\text { Apa Metode dan Teknik Analisis yang } \\
\text { Digunakan? }\end{array}$ & Identifikasi metode dan teknik analis \\
\hline RQ2 & $\begin{array}{l}\text { Apakah perbankan syariah di Indonesia telah } \\
\text { menjalankan praktek relationship marketing? }\end{array}$ & $\begin{array}{l}\text { Mengindentifikasi praktek relationship marketing } \\
\text { pada perbankan syariah Indonesia }\end{array}$ \\
\hline RQ3 & $\begin{array}{l}\text { Apakah Praktek Relationship Marketing Mampu } \\
\text { Meningkatkan Loyalitas Nasabah Perbankan } \\
\text { Syariah Di Indonesia? }\end{array}$ & $\begin{array}{l}\text { Mengidentifikasi praktek relationship } \\
\text { marketing dalam meningkatkan loyalitas di } \\
\text { perbankan syariah Indonesia }\end{array}$ \\
\hline RQ4 & $\begin{array}{l}\text { Apakah Terdapat Kelemahan Dalam Praktek } \\
\text { Relationship Marketing Di Perbankan Syariah } \\
\text { Indonesia? }\end{array}$ & $\begin{array}{l}\text { Mengidentifikasi kelemahan praktek } \\
\text { relationship marketing perbankan syariah } \\
\text { Indonesia }\end{array}$ \\
\hline RQ5 & Apa solusi bagi perbankan syariah di Indonesia? & Mengidentifikasi solusi \\
\hline
\end{tabular}


Praktek Relationship Marketing dalam Menciptakan Loyalitas...

Fatimatul Fatmariyah, IskandarRitonga, Luluk Lathifah, Fathor AS

Strategi pencarian literatur digunakan untuk mendapatkan sumber-sumber yang relevan untuk menjawab research question(RQ). Proses pencarian dilakukan dengan menggunakan search engineGoogle Chrome: Google Cendekia, Portal Garuda dan Google untuk menemukan sumber primer.

Selanjutnya, kriteria inklusi dan eksklusi digunakan untuk memilih studi primer. Kriteria ini ditunjukkan pada Tabel 3.

Tabel 3. Kriteria Inklusi dan Eksklusi

\begin{tabular}{|c|c|c|}
\hline Kriteria & Inklusi & Ekslusi \\
\hline Database Literatur & $\begin{array}{l}\text { Google Cendekia, Portal Garuda dan } \\
\text { Google }\end{array}$ & $\begin{array}{l}\text { Non-Google Cendekia, Portal Garuda dan } \\
\text { Google }\end{array}$ \\
\hline Tipe Literatur & $\begin{array}{l}\text { 1. Jurnal (Artikel hasil penelitian di } \\
\text { Indonesia) } \\
\text { 2. Artikel Full text }\end{array}$ & $\begin{array}{l}\text { 1. Jurnal (Konseptual), seri buku,buku, bab } \\
\text { dalam buku,prosiding. } \\
\text { 2. Non-Full text }\end{array}$ \\
\hline Bahasa & atau Indonesia & Non-Inggris at \\
\hline Periode Publikasi & & $<20$ \\
\hline Subjek & $\begin{array}{l}\text { Relationship } \\
\text { marketing/loyalitas/kesetiaan/retention }\end{array}$ & $\begin{array}{l}\text { tionship } \\
\text { ig/loyalitas/kesetiaan/retention }\end{array}$ \\
\hline Objek & Perbankan Syariah Indonesia & Non-Perbankan Syariah Indonesia \\
\hline
\end{tabular}

Studi primer yang dipilih diekstraksi kemudian dikumpulkan data yang berkontribusi untuk menjawab pertanyaan penelitian ini.

Selanjutnya melakukan penilaian kualitas untuk membimbing dalam interpretasi temuan sintesis dan untuk menentukan kekuatan kesimpulan yang diuraikan. Tujuan dari sintesis data adalah untuk mengumpulkan bukti dari studi yang dipilih untuk menjawab pertanyaan penelitian.Sintesis data dilakukan dengan mengelompokkan data-data hasil ekstraksi yang sejenis sesuai dengan hasil yang diukur untuk menjawab tujuan penelitian. Jurnal penelitian yang sesuai dengan kriteria inklusi dan kriteria eksklusi kemudian dikumpulkan dan dibuat ringkasan jurnal meliputi nama peneliti, tahun terbit jurnal, judul penelitian, metode dan ringkasan atau hasil temuan.

\section{RESULTS}

Hasil Search Strategy

Hasil search strategy yang ditampilkan pada tabel 5 dikelompokkan berdasarkan database jurnal untuk mempermudah melihat jumlah dan hasil jurnal yang diperoleh melalui search process.

Tabel 5. Hasil Search Strategy

\begin{tabular}{|l|l|l|l|l|}
\hline No & \multicolumn{1}{|c|}{ Item } & \multicolumn{1}{c|}{ Database } & Jumlah & Hasil \\
\hline 1 & $\begin{array}{l}\text { relationship marketing } \\
\text { dan loyalitas dan bank } \\
\text { syariah Indonesia }\end{array}$ & https://scholar.google.co.id/schhp?hl=id & 4.170 Judul & 49 Artikel \\
\hline 2 & $\begin{array}{l}\text { relationship marketing } \\
\text { dan loyalitas dan bank } \\
\text { syariah }\end{array}$ & https://garuda.kemdikbud.go.id/ \\
\hline 3 & $\begin{array}{l}\text { relationship marketing } \\
\text { dan loyalitas dan bank } \\
\text { syariah+pdf }\end{array}$ & https://google.com/search? & 70.000 Judul & 5 Artikel \\
\hline
\end{tabular}


Jurnal Studi Manajemen dan Bisnis

Vol. 8 (2) 2021: 14-26
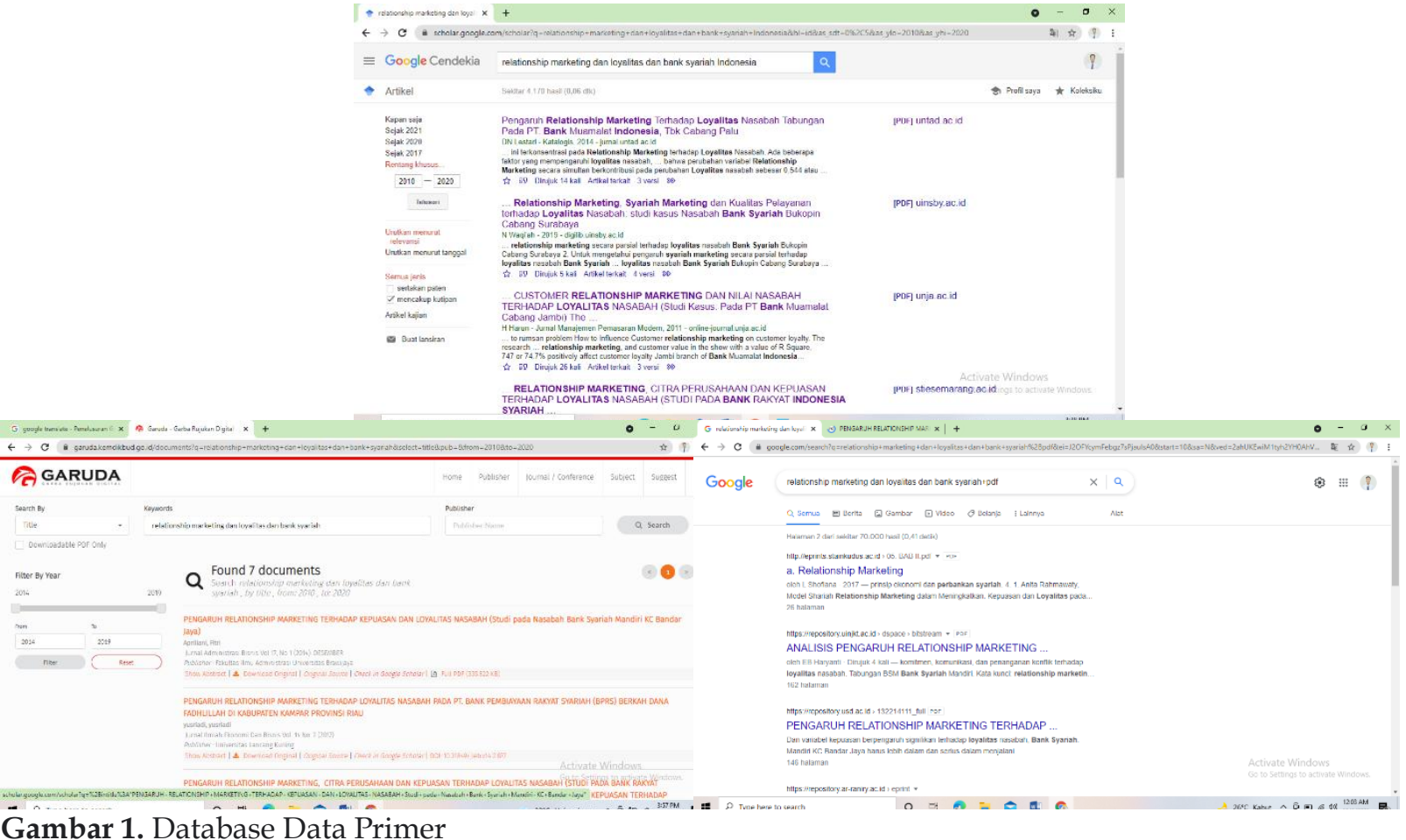

Hasil Seleksi Inklusi dan Eksklusi

Hasil seleksi akhir berdasarkan kriteria batasan

terdiri dari 11 artikel utama yang diterbitkan antara tahun 2010sampai dengan 2020dan cocok untuk dan pemasukan (inclusion and exclusion criteria) menjawab RQ dalam penelitian ini.

Tabel 6. Hasil Seleksi Inklusi dan Eksklusi

\begin{tabular}{|c|c|c|c|c|c|}
\hline No & Jurnal/Author & Judul & Desain/Indikator & Hasil & Database \\
\hline 1 & $\begin{array}{l}\text { Jurnal Aplikasi } \\
\text { Manajemen. Vol 9, } 3 \\
\text { (2011). p.953-961. } \\
\text { Mokhamad Arwani, } \\
\text { Djumilah Zain, } \\
\text { Surachman dan } \\
\text { Djumahir }\end{array}$ & $\begin{array}{lr}\text { Peran } & \text { Karakteristik } \\
\text { Individu } & \text { sebagai } \\
\text { Moderator } & \text { dan } \\
\text { Pemasaran } & \text { Relasional } \\
\text { sebagai } & \text { Mediator } \\
\text { Pengaruh } & \text { Kepuasan } \\
\text { terhadap Loyalitas (Studi } \\
\text { pada Nasabah Bank } \\
\text { Syariah di Jawa Timur) } \\
\end{array}$ & $\begin{array}{l}\text { Kuantitatif } \\
\text { Structural Equation } \\
\text { Model } \\
\text { 1. Kepercayaan } \\
\text { 2. Komitmen } \\
\text { 3. Komunikasi } \\
\text { 4. Penanganan } \\
\quad \text { Konflik }\end{array}$ & $\begin{array}{l}\text { Pemasaran } \\
\text { relasional } \\
\text { berpengaruh } \\
\text { terhadap loyalitas. }\end{array}$ & Cendekia \\
\hline 2 & $\begin{array}{l}\text { Jurnal Administrasi } \\
\text { Bisnis (JAB). Vol. 17, } \\
1 \text { (2014). p. 1-5. } \\
\text { Fitri Apriliani, } \\
\text { Srikandi Kumadji } \\
\text { dan Andriani } \\
\text { Kusumawati }\end{array}$ & 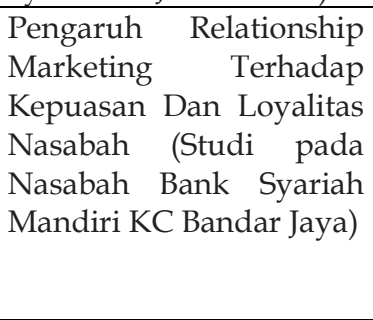 & $\begin{array}{l}\text { Kuantitatif : Path } \\
\text { analysis } \\
\text { 1. Trust } \\
\text { 2. Commitment } \\
\text { 3. Communication } \\
\text { 4. Conflict } \\
\text { Handling }\end{array}$ & $\begin{array}{l}\text { Relationship } \\
\text { marketing } \\
\text { berpengaruh pada } \\
\text { loyalitas }\end{array}$ & Garuda \\
\hline 3 & $\begin{array}{l}\text { Jurnal Manajemen } \\
\text { dan Bisnis Vol 11, } \\
\text { 1B (2015). p. 1-16. } \\
\text { Mares Setiani, Titin } \\
\text { Ekowati dan } \\
\text { Wijayanti }\end{array}$ & $\begin{array}{lr}\text { Pengaruh } & \text { Relationship } \\
\text { Marketing } & \text { Terhadap } \\
\text { Customer } & \text { Retention } \\
\text { Orientation } & \text { Nasabah } \\
\text { Bank Syariah Di } \\
\text { Kebumen }\end{array}$ & $\begin{array}{ll}\text { Kuantitatif : Regresi } \\
\text { linier berganda } \\
\text { 1. } \\
\text { 2. } \text { Celonging } \\
\text { 3. } \text { Customization } \\
\text { 4. } \text { Differentiation } \\
\text { 5. Personalization } \\
\text { 6. } & \text { Rewarding } \\
\text { 7. } & \text { Security } \\
\text { 8. } & \text { Convenience } \\
\end{array}$ & $\begin{array}{l}\text { Relationship } \\
\text { marketing } \\
\text { berpengaruh } \\
\text { terhadap customer } \\
\text { retention }\end{array}$ & Garuda \\
\hline 4 & Asy-Syir'ah Jurnal & Shariah & Kuantitatif : Path & Syariah relationship & Cendekia \\
\hline
\end{tabular}


Praktek Relationship Marketing dalam Menciptakan Loyalitas...

Fatimatul Fatmariyah, IskandarRitonga, Luluk Lathifah, Fathor AS

\begin{tabular}{|c|c|c|c|c|c|}
\hline & $\begin{array}{l}\text { Ilmu Syari'ah dan } \\
\text { Hukum Vol. 49, } 2 \\
\text { (2015). p. 356-385. } \\
\text { Anita Rahmawaty }\end{array}$ & $\begin{array}{l}\text { Relationship Marketing } \\
\text { dalam Meningkatkan } \\
\text { Kepuasan dan Loyalitas } \\
\text { pada Lembaga Keuangan } \\
\text { Mikro Syari'ah }\end{array}$ & $\begin{array}{ll}\text { analysis } \\
\text { 1. } & \text { Bonding } \\
\text { 2. } & \text { Empathy } \\
\text { 3. } & \text { Reciprocity } \\
\text { 4. } & \text { Trust } \\
\text { 5. } & \text { Commitment } \\
\text { 6. } & \text { Shared Value } \\
\text { 7. } & \text { Communication } \\
\text { 8. } & \text { Conflict } \\
& \text { Handling }\end{array}$ & $\begin{array}{l}\text { marketing } \\
\text { berpengaruh secara } \\
\text { tidak langsung } \\
\text { terhadap loyalitas }\end{array}$ & \\
\hline 5 & $\begin{array}{l}\text { Jurnal Ilmiah } \\
\text { Mahasiswa } \\
\text { Ekonomi } \\
\text { Manajemen Vol. 3, } 1 \\
\text { (2018).p. } 36-45 . \\
\text { Rizky Khaisar } \\
\text { Maulana dan } \\
\text { Mukhlis Yunus }\end{array}$ & $\begin{array}{lr}\text { Pengaruh } & \text { Pemasaran } \\
\text { Relasional } & \text { Terhadap } \\
\text { Loyalitas } & \text { Nasabah } \\
\text { Melalui } & \text { Kepuasan } \\
\text { Nasabah } & \text { Dan } \\
\text { Kepercayaan } & \text { Nasabah } \\
\text { Tabungan } & \text { Bank Bri } \\
\begin{array}{l}\text { Syariah Di Kota Banda } \\
\text { Aceh }\end{array} & \\
\end{array}$ & $\begin{array}{l}\text { Kuantitatif : } \\
\text { Hierarchical Linear } \\
\text { Modeling (HLM) } \\
\text { 1. Kepercayaan } \\
\text { 2. Komitmen } \\
\text { 3. Mutualitas } \\
\text { 4. Hubungan } \\
\quad \text { Jangka Panjang }\end{array}$ & $\begin{array}{l}\text { Pemasaran } \\
\text { relasional } \\
\text { berpengaruh } \\
\text { terhadap loyalitas }\end{array}$ & Cendekia \\
\hline 6 & $\begin{array}{l}\text { Jurnal STIE } \\
\text { Semarang Vol 10, } 1 \\
(2018) \cdot \text { p. 17-37. } \\
\text { Nurudin }\end{array}$ & \begin{tabular}{lr} 
Pengaruh & Relationship \\
Marketing, & Citra \\
Perusahaan & Dan \\
Kepuasan & Terhadap \\
Loyalitas Nasabah (Studi \\
Pada Bank Rakyat \\
Indonesia Syariah Kantor \\
\multicolumn{2}{l}{ Cabang Semarang) }
\end{tabular} & $\begin{array}{l}\text { Kuantitatif : Regresi } \\
\text { linear berganda } \\
\text { 1. Bonding } \\
\text { 2. Commitment } \\
\text { 3. Trust } \\
\text { 4. Handling } \\
\text { 5. Complaints } \\
\text { Communication }\end{array}$ & $\begin{array}{l}\text { Relationship } \\
\text { marketing } \\
\text { berpengaruh } \\
\text { terhadap loyalitas }\end{array}$ & Cendekia \\
\hline 7 & $\begin{array}{l}\text { EKOMBIS } \\
: \quad \text { JEVIEW } \\
\text { Ekonomi dan Bisnis } \\
\text { Vol 6, } 2 \text { (2018).p. } \\
200-209 . \\
\text { Meiffa Herfianti dan } \\
\text { Diman } \\
\text { Saputra }\end{array}$ & $\begin{array}{l}\text { Hubungan Implementasi } \\
\text { Relationship Marketing } \\
\text { Dengan Loyalitas } \\
\text { Nasabah Pada Pt. Bank } \\
\text { Bri Syariah Kantor } \\
\text { Cabang Bengkulu }\end{array}$ & $\begin{array}{ll}\text { Kuantitatif : Korelasi } \\
\text { Spearman Rank } \\
\text { 1. Memahami } \\
\text { Harapan } \\
\text { Pelanggan } \\
\text { 2. Kerjasama } \\
\text { Dengan } \\
\text { Pelanggan (Co- } \\
\text { Operation) } \\
\text { 3. Total Quality } \\
\text { Managenent } \\
\text { 4. Pemberdayaan } \\
\text { Karyawan }\end{array}$ & $\begin{array}{l}\text { Hubungan positif } \\
\text { antara pemasaran } \\
\text { relaionship dengan } \\
\text { loyalitas }\end{array}$ & Garuda \\
\hline 8 & $\begin{array}{l}\text { JMI Jurnal } \\
\text { Manajemen dan } \\
\text { Inovasi Vol 9, } 2 \\
(2018) \cdot \text { p. } 44-49 . \\
\text { Yuliana, Edwar } \\
\text { M.Nur, Reza Juanda } \\
\text { dan Sri Wahyuni } \\
\text { Yusni }\end{array}$ & $\begin{array}{lr}\text { Pengaruh } & \text { Relationship } \\
\text { Marketing } & \text { Dan } \\
\text { Keunggulan } & \text { Produk } \\
\text { Terhadap } & \text { Kesetiaan } \\
\text { Nasabah Pada } & \text { Pt.Bank } \\
\text { Syariah Mandiri Cabang } \\
\text { Banda Aceh }\end{array}$ & $\begin{array}{l}\text { Kuantitatif : Regresi } \\
\text { linear berganda } \\
\text { 1. Kepercayaan } \\
\text { 2. Komitmen } \\
\text { 3. Kompetensi } \\
\text { 4. Komunikasi }\end{array}$ & $\begin{array}{l}\text { Relationship } \\
\text { Marketing } \\
\text { berpengaruh } \\
\text { terhadap kesetiaan } \\
\text { nasabah }\end{array}$ & Cendekia \\
\hline 9 & $\begin{array}{l}\text { Eko dan Bisnis (Riau } \\
\text { Economics and } \\
\text { Business Review) } \\
\text { Vol 9,4 (2018) } \\
\text { p.231-240. } \\
\text { Hendrayani }\end{array}$ & 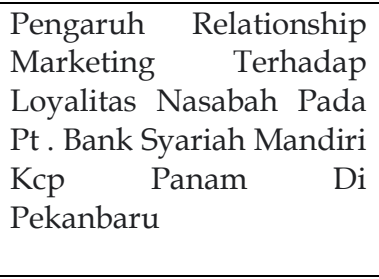 & $\begin{array}{l}\text { Kuantitatif : Regresi } \\
\text { linier sederhana } \\
\text { 1. Trust } \\
\text { 2. Commitment } \\
\text { 3. Communication }\end{array}$ & $\begin{array}{l}\text { Relationship } \\
\text { Marketing } \\
\text { berpengaruh } \\
\text { terhadap Loyalitas } \\
\text { Nasabah }\end{array}$ & Google \\
\hline 10 & $\begin{array}{l}\text { Al-Iqtishod : Jurnal } \\
\text { Ekonomi } \\
\text { Vol 2, } 1 \text { (2019). p. } \\
\text { 103-122. }\end{array}$ & 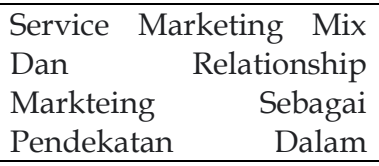 & $\begin{array}{l}\text { Kuantitatif : Analisis } \\
\text { factor } \\
\text { 1. Trust } \\
\text { 2. Comitmen }\end{array}$ & $\begin{array}{l}\text { Faktor relationship } \\
\text { marketing tebukti } \\
\text { menentukan } \\
\text { loyalitas nasabah }\end{array}$ & Cendekia \\
\hline
\end{tabular}


Jurnal Studi Manajemen dan Bisnis

Vol. 8 (2) 2021: 14-26

\begin{tabular}{|c|c|c|c|c|c|}
\hline & $\begin{array}{ll}\text { Rudhy } & \text { Dwi } \\
\text { Chrysnaputra } & \text { dan } \\
\text { Sri Mulyani } & \end{array}$ & $\begin{array}{l}\text { Menentukan Loyalitas } \\
\text { Nasabah Penabung Bank } \\
\text { Syariah (Studi Pada Bank } \\
\text { Syariah Umum Bumn Di } \\
\text { Kota Malang) }\end{array}$ & $\begin{array}{ll}\text { 3. } & \text { Communication } \\
\text { 4. } & \text { Empathy } \\
\text { 5. } & \text { Share Value }\end{array}$ & & \\
\hline 11 & 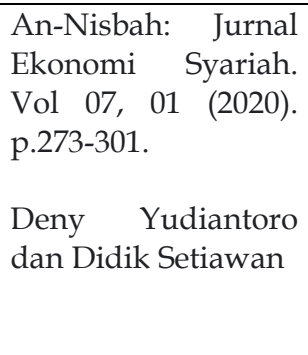 & 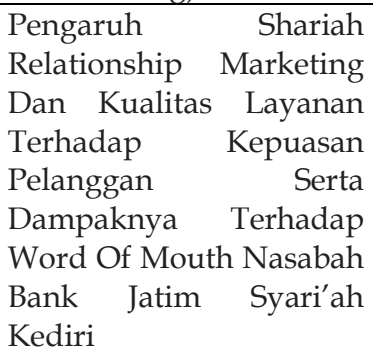 & $\begin{array}{l}\text { Kuantitatif : } \\
\text { Structural Equation } \\
\text { Model } \\
\text { 1. Bonding } \\
\text { 2. Commitment } \\
\text { 3. Trust } \\
\text { 4. Handling } \\
\text { 5. Complaints } \\
\text { Communication }\end{array}$ & $\begin{array}{l}\text { Shariah relationship } \\
\text { marketing } \\
\text { berpengaruh } \\
\text { terhadap word of } \\
\text { mouth }\end{array}$ & Cendekia \\
\hline
\end{tabular}

\section{DISCUSSION}

RQ1. Apa Metode dan Teknik Analisis yang Digunakan?

Berdasarkan hasil studi Systematic Literature Review, menunjukkan bahwa secara keseluruhan metode penelitian yang digunakan oleh para Table 7.Persamaan dan Perbedaan Desain Penelitian

\begin{tabular}{|c|c|c|c|}
\hline Peneliti & Desain & Peneliti & Desain \\
\hline $\begin{array}{l}\text { Mokhamad } \\
\text { Arwani, Djumilah } \\
\text { Zain, Surachman } \\
\text { dan Djumahir }\end{array}$ & $\begin{array}{l}\text { Kuantitatif : } \\
\text { SEM } \\
\text { Accidental sampling } \\
\text { Sampel } 112 \text { orang }\end{array}$ & $\begin{array}{l}\text { Meiffa Herfianti dan } \\
\text { Diman Wido Saputra }\end{array}$ & $\begin{array}{l}\text { Kuantitatif: } \\
\text { Korelasi Spearman } \\
\text { Rank } \\
\text { Tidak tertulis dalam } \\
\text { artikel }\end{array}$ \\
\hline $\begin{array}{l}\text { Fitri Apriliani, } \\
\text { Srikandi Kumadji } \\
\text { dan Andriani } \\
\text { Kusumawati }\end{array}$ & $\begin{array}{l}\text { Kuantitatif : } \\
\text { Path analysis } \\
\text { Accidental sampling } \\
\text { Sampel } 101 \text { orang }\end{array}$ & $\begin{array}{c}\text { Yuliana, Edwar } \\
\text { M.Nur, Reza Juanda } \\
\text { dan Sri Wahyuni } \\
\text { Yusni }\end{array}$ & $\begin{array}{l}\text { Kuantitatif: } \\
\text { Regresi linear } \\
\text { berganda } \\
\text { Non probability } \\
\text { sampling } \\
\text { Sampel 150 orang }\end{array}$ \\
\hline $\begin{array}{c}\text { Mares Setiani, Titin } \\
\text { Ekowati dan } \\
\text { Wijayanti }\end{array}$ & $\begin{array}{l}\text { Kuantitatif: } \\
\text { Regresi linier berganda } \\
\text { Purposive sampling } \\
\text { Sampel } 100 \text { nasabah }\end{array}$ & Hendrayani & $\begin{array}{l}\text { Kuantitatif : } \\
\text { Regresi linier } \\
\text { sederhana } \\
\text { Sampel 100 orang }\end{array}$ \\
\hline Anita Rahmawaty & $\begin{array}{l}\text { Kuantitatif: } \\
\text { Path analysis } \\
\text { Convenience sampling } \\
\text { Sampel } 185 \text { responden }\end{array}$ & $\begin{array}{c}\text { Rudhy Dwi } \\
\text { Chrysnaputra dan } \\
\text { Sri Mulyani }\end{array}$ & $\begin{array}{l}\text { Kuantitatif: } \\
\text { Analisis factor } \\
\text { Insidental sampling } \\
\text { Sampel } 192 \text { nasabah }\end{array}$ \\
\hline $\begin{array}{l}\text { Rizky Khaisar } \\
\text { Maulana dan } \\
\text { Mukhlis Yunus }\end{array}$ & $\begin{array}{l}\text { Kuantitatif: } \\
\text { Hierarchical Linear Modeling } \\
\text { (HLM) } \\
\text { Purposive sampling } \\
\text { Sampel 150 orang }\end{array}$ & $\begin{array}{c}\text { Deny Yudiantoro } \\
\text { dan Didik Setiawan }\end{array}$ & $\begin{array}{l}\text { Kuantitatif: } \\
\text { SEM } \\
\text { Purposive sampling. } \\
\text { Sampel } 170 \text { orang }\end{array}$ \\
\hline & Nurudin & \multicolumn{2}{|l|}{$\begin{array}{l}\text { Kuantitatif : } \\
\text { Regresi linear berganda } \\
\text { Insidental sampling } \\
\text { Sampel } 100 \text { responden }\end{array}$} \\
\hline
\end{tabular}

Penggunaan metode kauntitatif dengan pendekatan kuesioner tertutup ini dilakukan karena adanya berbagai keterbatasan peneliti peneliti adalah pendekatan kuantitatif dengan pendekatan alat statistic yang berbeda-beda. Tabel 7 menunjukkan persamaan dan perbedaan tersebut. 
Praktek Relationship Marketing dalam Menciptakan Loyalitas...

Fatimatul Fatmariyah, IskandarRitonga, Luluk Lathifah, Fathor AS

tujuan yang di tetapkan. Hasil studi juga menunjukkan bahwa penggunaan alat analisis statistic SEM lebih baik dari alat analisis yang lainnya karena lebih konprehensif dalam menganalisis dan memberikan informasi dan pandangan tentang praktek relationship marketing di perbankan syariah Indonesia.

Secara keseluruhan hasil studi ini tidak ditemukan adanya penelitian yang menggunakan pendekatan kualitatif maupun mix methods. Sehingga ke depan, ada peluang bagi peneliti lain untuk menggunakan pendekatan kualitatif maupun mix methods dalam penelitiannya untuk mendapatkan informasi yang sangat konprehensif tentang praktek relationship marketing di perbankan syariah Indonesia.

RQ2. Apakah Perbankan Syariah Di Indonesia Telah Menjalankan Praktek Relationship Marketing?
Tabel 6diatas menjawab RQ2, yang menunjukkan bahwa perbankan syariah di Indonesia telah mengimplementasikan praktekpraktek relationship marketing. (Arwani, 2011; Mares, 2012; Apriliani, 2014; Rahmawaty, 2015; Maulana dan Yunus, 2017; Yuliana et al., 2018; Hendrayani, 2018; Herfianti dan Saputra, 2018; Nurudin, 2018; Chrisnaputra dan Mulyani, 2019; Yudiantoro dan Setiawan, 2020). Praktek relationship marketing yang dilaksanakan oleh perbankan syariah di Indonesia menggunakan berbagai instrument yang dikembangkan dari teori dasar relationship marketing. Instrument tersebut kemudian disesuaikan dengan kondisi lingkungan dan budaya yang berlaku pada perbankan syariah tersebut beroperasi. Sehingga instrument yang digunakan oleh para peneliti pada perbankan syariah di Indonesia memiliki kesamaan dan perbedaan sebagaimana tabel 8 berikut :

Table 8.Persamaan dan Perbedaan Penggunaan Indikator Relationship Marketing

\begin{tabular}{|c|c|c|c|}
\hline \multirow[b]{2}{*}{$\begin{array}{l}\text { Peneliti } \\
\text { Mokhamad } \\
\text { Arwani, Djumilah } \\
\text { Zain, Surachman } \\
\text { dan Djumahir }\end{array}$} & Indikator & Peneliti & Indikator \\
\hline & $\begin{array}{ll}\text { 1. } & \text { Kepercayaan } \\
\text { 2. } & \text { Komitmen } \\
\text { 3. } & \text { Komunikasi } \\
\text { 4. } & \text { Penanganan Konflik }\end{array}$ & Nurudin & $\begin{array}{ll}\text { 1. } & \text { Bonding } \\
\text { 2. } & \text { Commitment } \\
\text { 3. } & \text { Trust } \\
\text { 4. } & \text { Handling Complaints } \\
\text { 5. } & \text { Communication }\end{array}$ \\
\hline $\begin{array}{lr}\text { Fitri } & \text { Apriliani, } \\
\text { Srikandi } & \text { Kumadji } \\
\text { dan } & \text { Andriani } \\
\text { Kusumawati }\end{array}$ & $\begin{array}{ll}\text { 1. } & \text { Trust } \\
\text { 2. } & \text { Commitment } \\
\text { 3. } & \text { Communication } \\
\text { 4. } & \text { Conflict Handling }\end{array}$ & $\begin{array}{l}\text { Meiffa } \\
\text { Herfianti } \\
\text { dan Diman } \\
\text { Wido } \\
\text { Saputra }\end{array}$ & $\begin{array}{ll}\text { 1. } & \text { Memahami Harapan } \\
& \text { Pelanggan } \\
\text { 2. Kerjasama Dengan Pelanggan } \\
\text { 3. Total Quality Managenent } \\
\text { 4. Pemberdayaan Karyawan }\end{array}$ \\
\hline $\begin{array}{l}\text { Mares Setiani, Titin } \\
\text { Ekowati dan } \\
\text { Wijayanti }\end{array}$ & $\begin{array}{ll}\text { 1. } & \text { Belonging } \\
\text { 2. } & \text { Communication } \\
\text { 3. } & \text { Customization } \\
\text { 4. } & \text { Differentiation } \\
\text { 5. } & \text { Personalization } \\
\text { 6. } & \text { Rewarding } \\
\text { 7. } & \text { Security } \\
\text { 8. } & \text { Convenience }\end{array}$ & $\begin{array}{l}\text { Yuliana, } \\
\text { Edwar } \\
\text { M.Nur, } \\
\text { Reza } \\
\text { Juanda dan } \\
\text { Sri } \\
\text { Wahyuni } \\
\text { Yusni }\end{array}$ & $\begin{array}{ll}\text { 1. } & \text { Kepercayaan } \\
\text { 2. } & \text { Komitmen } \\
\text { 3. } & \text { Kompetensi } \\
\text { 4. } & \text { Komunikasi }\end{array}$ \\
\hline $\begin{array}{ll}\text { Rudhy } & \text { Dwi } \\
\text { Chrysnaputra } & \text { dan } \\
\text { Sri Mulyani } & \end{array}$ & $\begin{array}{ll}\text { 1. } & \text { Nilai tambah } \\
\text { 2. } & \text { Komunikasi } \\
\text { 3. } & \text { Komitmen } \\
\text { 4. } & \text { Empaty }\end{array}$ & Hendrayani & $\begin{array}{ll}\text { 1. } & \text { Trust } \\
\text { 2. } & \text { Commitment } \\
\text { 3. } & \text { Communication }\end{array}$ \\
\hline $\begin{array}{lr}\text { Rizky } & \text { Khaisar } \\
\text { Maulana dan } & \text { dakhlis Yunus }\end{array}$ & $\begin{array}{ll}\text { 1. } & \text { Kepercayaan } \\
\text { 2. } & \text { Komitmen } \\
\text { 3. } & \text { Mutualitas } \\
\text { 4. } & \text { Hubungan Jangka Panjang } \\
\end{array}$ & \multirow[t]{2}{*}{$\begin{array}{l}\text { Anita } \\
\text { Rahmawaty }\end{array}$} & \multirow{2}{*}{$\begin{array}{ll}\text { 1. } & \text { Bonding } \\
\text { 2. } & \text { Trust } \\
\text { 3. } & \text { Commitment } \\
\text { 4. } & \text { Communication } \\
\text { 5. } & \text { Conflict Handling }\end{array}$} \\
\hline $\begin{array}{lr}\text { Deny } & \text { Yudiantoro } \\
\text { dan } & \text { Didik } \\
\text { Setiawan } & \end{array}$ & $\begin{array}{ll}\text { 1. } & \text { Bonding } \\
\text { 2. } & \text { Commitment } \\
\text { 3. } & \text { Trust } \\
\text { 4. } & \text { Handling Complaints } \\
\text { 5. } & \text { Communication }\end{array}$ & & \\
\hline
\end{tabular}


Secara keseluruhan hasil studi ini menggunakan sebagian indikator tersebut dalam implemetasi relationship marketingnya, tidak ditemukan dalam studi yang secara keseluruhan menggunakan seluruh indikator yang ada yang mungkin tidak disebutkan atau tidak ada pada perbankan syariah. Sehingga ke depan, ada peluang bagi peneliti untuk menggunakan atau mengadopsi seluruh indikator tersebut dalam penelitiannya untuk mengetahui secara lebih mendalam tentang praktek relationship marketing di perbankan syariah Indonesia demi perbaikan kinerja yang disesuaikan dengan kondisi lingkungan dan budaya organisasinya.

Disamping itu, implementasi tersebut masih belum sepenuhnya soul of marketing ini menjadi bagian terpenting dalam perbankan syariah, hal tersebut terbutki dari masih kecilnya nilai praktek relationsdhip marketing di perbankan syariah yang berada di bawah 50\%. Masih adanya nasabah yang akan berpindah, kurangnya pengetahuan dan pemahaman masyarakat terhadap perbankan syariah serta adanya berbagai keraguan masyarakart terhadap kepatuhan syariah (Shariah Compliance) pada perbankan syariah. Sehingga perlu strategi dari perbankan syariah untuk meningkatkan kinerjanya melalui impelementasi relationship marketing yang lebih baik dan efektif.

Berdasarkan studi tersebut, artinya secara keseluruhan hasil studi literature menunjukkan bahwa pihak manajemen perbankan syariah sudah memahami pentingnya praktek relationship marketing di perusahaannya karena akan menjamin kinerja perbankansyariah menjadi lebih baik.

RQ3. Apakah Praktek Relationship Marketing Mampu Meningkatkan Loyalitas Nasabah Perbankan Syariah Di Indonesia?

Tujuan akhir dari praktek relationship marketing adalah meningkatnya loyalitas nasabah. Hasil studi LSR ini menunjukkan bahwa prkatek-praktek relationship marketing yang baik pada bank syariah di Indonesia telah mampu menciptakan loyalitas nasabah baik secara langsung maupun secara tidak langsung melalui intervensi atau moderasi instrument lain yang menjadi penggeraknya.(Arwani, 2011; Mares, 2012; Apriliani, 2014; Rahmawaty, 2015; Maulana dan Yunus, 2017; Yuliana et al., 2018; Hendrayani, 2018; Herfianti dan Saputra, 2018; Nurudin, 2018; Chrisnaputra dan Mulyani, 2019; Yudiantoro dan Setiawan, 2020). Hasil studi juga menunjukkan bahwa praktek-praktek relationship marketing di perbankan syariah Indonesia bekerja dengan baik karena sudah mampu memberikan kontribusi pengaruh di atas 50\%. (Arwani, 2011; Apriliani, 2014; Hendrayani, 2018; Herfianti dan Saputra, 2018; Yuliana et al., 2018). Relationship marketing yang dibangun melalui indikator relationship marketing yang dilakukan perbankan syariah selama ini mampu mempengaruhi loyalitas nasabah. (Rahmawaty, 2015). Perusahaan yang sukses adalah perusahaan yang mampu menjalin relationship jangka panjang dengan nasabahnya. Relationship jangka panjang berarti pelanggan yang loyal di mana kebutuhan dan keinginannya terpuaskan. (Tjahyadi, 2010).

Praktek relationship marketing pada perbankan syariah ini akan semakin meningkat jika ada intervensi variable atau faktor lain yang sesuai baik itu dari sisi bauran pemasaran, kepuasan atas layanan, keunggulan produk, nilai, kepatuhan syariah dan lain sebagainya, karena selain adanya interaksi antara pemasaran relasional yang dicerminkan oleh berbagai indikatornya dan adanya karakteristik individu (demografi, sosial, pendapatan, dan pengetahuan) yang secara nyata telah meningkatkan pengaruh pemasaran relasional terhadap loyalitas. Hal itu berarti bahwa pemasaran relasional yang terjalin semakin kuat antara nasabah dengan pihak bank syariah dapat meningkatkan loyalitas. Interaksi antara pemasaran relasional dengan karakteristik individu telah terbukti dapat meningkatkan loyalitas. (Arwani, 2011).

Sehingga perlu juga pengkajian secara mendalam oleh pihak perbankan syariah terhadap variabel-variabel di luar konsep relationship marketingansich. Karena tentu seluruh aktifitas dan konsep yang di bangun akan berpengaruh terhadap loyalitas nasabah.

Namun disamping itu, walaupun praktek relationship marketingsudah dilaksanakan oleh perbankan syariah, hasil studi juga menunjukkan bahwa praktek ini di beberapa perbankan syariah masih memiliki pengaruh yang kecil dalam menciptakan loyalitas nasabah baik secara langsung maupun tidak langsung. Karena rata-rata nilai pengaruhnya kecil yaitu berada di bawah $50 \%$ bahkan cendrung ada yang negatif. (Arwani, 2011; Apriliani, 2014; Rahmawaty, 2015; Maulana dan Yunus, 2017; Nurudin, 2018; Yudiantoro dan Setiawan, 2020). Hal tersebut di sebabkan karena nasabah kadang menganggap bahwa suatu tawaran layanan yang diberikan bukan hal yang 
penting tetapi nasabah lebih mementingkan bentuk tawaran yang lainnya yang sesuai dengan kebutuhannya yang dapat memenuhi kebutuhan nasabah, atau nasabah Bank Syariah menganggap bahwa tawaran tersebut belum sesuai dengan yang diharapkan. (Mares, 2012). Selain itu nasabah yang menggunakan jasa lembaga keuangan syariah, sebagian memiliki kecenderungan untuk berhenti menjadi nasabah, antara lain karena keraguan akan konsistensi penerapan prinsip syariah. Secara implisit, hal tersebut menunjukkan bahwa praktik lembaga keuangan syariah selama ini kurang memperhatikan prinsip-prinsip syariah, baik dalam customer value maupun keunggulan produk syariahnya. Hal ini juga akan berdampak pada loyalitas nasabah menggunakan jasa lembaga keuangan syariah.

Kondisi tersebut akan mengganngu pertumbuhan bank syariah, sehingga Ifhamdalam (Arwani, 2011) mengungkapkan bahwa pertumbuhan nasabah bank syariah masih rendah. Rendahnya pertumbuhan nasabah bank syariah dikarenakan lemahnya loyalitas nasabah bank syariah, sebagai mana juga dikemukakan oleh Hafasnuddindalam (Arwani, 2011) bahwa hanya $33,75 \%$ saja nasabah bank syariah yang loyal dalam bentuk kesediaan nasabah untuk melakukan pembelian ulang dan merekomendasikan bank syariah kepada pihak lain. Salah satu yang menjadi faktor penting dari loyalitas nasabah adalah kepuasan. Apabila nasabah merasa puas, maka nasabah tidak akan segan merekomendasikan untuk mengajak orang lain turut serta menjadi nasabah bank tersebut.(Arwani, 2011)

Secara keseluruhan bahwa relationshoip marketing di perbankan syariah di Indoensia telah menciptakan loyalitas nasabah, jika relationship marketing semakin di tingkatkan, maka akan menyebabkan loyalitas nasabah bank syariah semakin tinggi pula. Hal tersebut menunjukkan bahwa perlu kerja keras dari perbankan syariah untuk meningkatkan kinerjanya dari berbagai sisi. Karena nasabah memiliki perspektif yang berbeda dalam menilai kinerja perbankan syariah

RQ4. Apakah Terdapat Kelemahan dalam Praktek Relationship Marketing di Perbankan Syariah Indonesia?

Hasil studi menunjukkan bahwa praktek relationshipmarketing di perbankan syariah masih rendah karena sebagain besar hasil studi memiliki nilai pengaruh di dibawah $50 \%$ baik dari sisi variabel maupun dari sisi indikator yang digunakan. (Arwani, 2011; Apriliani, 2014;
Rahmawaty, 2015; Maulana dan Yunus, 2017; Nurudin, 2018; Yudiantoro dan Setiawan, 2020). Artinya bahwa masih terdapat kelemahan dalam implementasinya. Namun studi ini tidak menemukan ulasan dari sisi internal atau penjelasan dari pihak manajeman bank syariah tentang kendala yang dihadapi oleh perbankan dalam implementasi relationship marketing. Secara eksternal kelemahan ini disebabkan oleh berbagai hal yaitu nasabah yang telah menjadi nasabah bank konvensional tidak ada yang berniat untuk memindahkan rekening mereka ke bank syariah, nasabah berpendapat bunga sama dengan riba dan ada yang mengaku tidak paham tentang bank syariah (Arwani, 2011), selain itu kelemahankelemahan ini tentu karena di sebabkan oleh Sumber Daya Insani (SDI) yang dimiliki terkait kemampuan dan pengetahuan.

Oleh karena itu diperlukan suatu strategi yang dibangun oleh perbankan syariah yang bertujuan untuk meyakinkan masyarakat bahwa perbankan syariah memiliki kelebihan tersendiri dibandingkan dengan bank konvensional.

RQ5. Apa Solusi bagi Perbankan Syariah Di Indonesia?

Berdasarkan kondisi empiris, hasil studi menunjukkan bahwa beberapa solusi secara umum yang perlu dipertimbangan oleh perbankan syariah antara lain : Meningkatkan penerapan indikator relationship marketing yang baik dan tepat, melakukan edukasi, penyuluhan, sosialisasi dan memberikan pemahaman terutama terhadap umat Islam, meyakinkan nasabah, meningkatkan kualitas pelayanan, meningkatkan keunggulan produk, tidak membedakan pelayanan kepada nasabah, mengakomodir kepentingan nasabah, menjaga konsistensi dan meningkatkan kemampuan petugas.(Arwani, 2011; Mares, 2012; Apriliani, 2014; Maulana dan Yunus, 2017; Herfianti dan Saputra, 2018; Nurudin, 2018; Yuliana et al., 2018; Chrisnaputra dan Mulyani, 2019; Yudiantoro dan Setiawan, 2020).

\section{CONCLUSIONS}

Hasil Systematic Literature Review menunjukkan bahwa secara keseluruhan metode penelitian yang digunakan adalah kuantitatif dengan alat statistic yang berbeda-beda dan belum ada yang menggunakan pendekatan kualitatif dan mix methods. Perbankan syariah di Indonesia telah mengimplementasikan praktek-praktek relationship marketing tetapi sebagian besar masih memiliki pengaruh yang rendah. Praktek-praktek relationship 
marketing yang baik pada bank syariah di Indonesia telah mampu menciptakan loyalitas nasabah baik secara langsung maupun secara tidak langsung tetapi sebagian besar memiliki pengaruh yang rendah. Praktek relationship marketing di perbankan syariah masih rendah karena sebagian besar hasil studi memiliki nilai pengaruh di dibawah $50 \%$ baik dari sisi variabel maupun dari sisi indikator. Secara umum solusi yang perlu dipertimbangan antara lain : Meningkatkan penerapan indikator relationship marketing yang baik dan tepat, melakukan edukasi, penyuluhan, sosialisasi dan memberikan pemahaman terutama terhadap umat Islam, meyakinakan nasabah, meningkatkan kualitas pelayanan, meningkatkan keunggulan produk, tidak membedakan pelayanan kepada nasabah, mengakomodir kepentingan nasabah, menjaga konsistensi dan meningkatkan kemampuan petugas.

Implikasi teoritis dan praktis dari studi ini memberikan benefit dalam pengembangan teori relationship marketing pada perbankan syariah dan menambah wawasan baru tentang praktek-praktek relationship marketing pada perbankan syariah khususnya terkait indikator-indikator yang layak dan tepat untuk dikembangkan dan diterapkan. Secara praktis studi ini menemukan referensi strategibaru yang perlu dikembangkan perbankan syariah di Indonesia. Selain itu, pentingnya implementasi relationship marketing pada perbankan syariah dalam membantu perkembangan perbankan syariah Indonesia di masa depan.

Studi ini memiliki keterbatasan baik dari sisi metodologi seperti media pencarian yang hanya menggunakan google cendekia, Portal Garuda dan Google, sampel 11 artikel. Saran untuk peneliti selanjutnya baik secara konseptual maupun empiris adalah menggunakan sumber media yang lebih baik, penelitian pendekatan kualitatif dan mix methods yang belum dilakukan.

\section{REFERENCES}

Apriliani, F. (2014). Pengaruh Relationship Marketing Terhadap Kepuasan dan Loyalitas Nasabah (Studi pada Nasabah Bank Syariah Mandiri KC Bandar Jaya).Jurnal Administrasi Bisnis, 17(1), 1-5.

Arwani, M. (2011). Peran Karakteristik Individu sebagai Moderator dan Pemasaran Relasional sebagai Mediator Pengaruh Kepuasan terhadap Loyalitas (Studi pada Nasabah Bank Syariah di Jawa Timur). JAM: Jurnal Aplikasi Manajemen, 9(3), 953-961.

Chrisnaputra, D. R. dan Mulyani, S. (2019). Service
Marketing Mix dan Relationship Marketing Sebagai Pendekatan Dalam Menentukan Loyalitas Nasabah Penabung Bank Syariah. AlIqtishod: Jurnal Ekonomi Syariah, 2(1), 103-122. Available at: http:/ / ejournal.iaiskjmalang.ac.id/index.php/ iqtis/article/view/58.

Diantara, L. dan Samsir. (2015). Analisis Relationship Marketing Terhadap Customer Satisfaction dan Customer Retention Pada Nasabah Bank Muamalat Cabang BangkinangKabupaten Kampar. Jurnal Tepak Manajemen Bisnis, VII(1).

Grönroos, C. (1994). From Marketing Mix to Relationship Marketing: Towards a Paradigm Shift in Marketing. Management Decision, 32(02), 4-20.

Harun, Nurul Aida., Noor, M. N. M. and Rahman, A. H. A. (2018). Relationship Marketing in Insurance Industry: A Systematic Analysis of Literatures. Advances in Economics, Business and Management Research,57(1), 191-199. doi: 10.2991/piceeba-18.2018.47.

Harun, Nurul Aida., Noor, M. N. M. and Ramasamy, S. (2019). Relationship Marketing and Insurance: A Systematic Literature Review. Scientific International (Lahore), 31(2), 255-260.

Hendrayani. (2018). Pengaruh Relationship Marketing Terhadap Loyalitas Nasabah Pada PT Bank Syariah Mandiri KCP Panam Pekanbaru. Eko dan Bisnis (Riau Economic and Bussiness Reviewe), 9(4), 231-240.

Herfianti, M. dan Saputra, D. W. (2018). Hubungan Implementasi Relationship Marketing Dengan Loyalitas Nasabah Pada PT. Bank BRI Syariah Kantor Cabang Bengkulu. EKOMBIS REVIEW: Jurnal Ilmiah Ekonomi dan Bisnis, 6(2), 200-209. doi: 10.37676/ekombis.v6i2.613.

Kartajaya, Hermawan., Yuswohadi, Dewi Madyani, B. D. I. (2003).Marketing In Venus. Jakarta: PT. Gramedia Pustaka Utama.

Kotler, P. \& G. A. (2010) Prinsip-Prinsip Pemasaran. 12th edn. Jakarta.

Latifah, L. dan Ritonga, I. (2020). Systematic Literature Review (SLR): Kompetensi Sumber Daya Insani Bagi Perkembangan Perbankan Syariah Di Indonesia.Al Maal: Journal of Islamic Economics and Banking, 2(1), 63-80. doi: 10.31000/almaal.v2i1.2763.

Mares, S. (2012). Pengaruh Relationship Marketing Terhadap Customer Retention Orrientation. SEGMEN: Jurnal Manajemen dan Bisnis,11(1B), 19-28. Available at: http://s- 
space.snu.ac.kr/handle/10371/54193\%0Ahttp: / / repository.umpwr.ac.id:8080/bitstream/ha ndle/123456789/2633/102210062-Mares Setiani.pdf?sequence $=1$.

Martini, L. K. B. (2013). Relationship Marketing, Customer Satisfaction, Customer Commitment Dan Customer Loyalty (Studi Pada Sebuah Bank Nasional Di Denpasar).Buletin Studi Ekonomi, 18(1), pp. 9-25.

Maulana, R. K. and Yunus, M. (2017). Pengaruh Pemasaran Relasional Terhadap Loyalitas Nasabah Melalui Kepuasan Nasabah dan Kepercayaan Nasabah Tabungan Bank BRISyariah Di Kota Banda Aceh. Jurnal Ilmiah Mahasiswa Ekonomi Manajemen, 3(1), 36-45.

Nurudin. (2018). Pengaruh Relationship Marketing, Citra Perusahaan dan Kepuasan Terhadap Loyalitas Nasabah (Studi Pada Bank Rakyat Indonesia Syariah Kantor Cabang Semarang). Jurnal Stie Semarang, 10(1), 17-37. doi: 10.33747/stiesmg.v10i1.84.

Otoritas Jasa Keuangan. (2020). Laporan Perkembagan Keuangan Syariah Indonesia 2020. Jakarta: Otoritas Jasa Keuangan Republik Indonesia, 1-153.

Rahmawaty, A. (2015). Model Shariah Relationship Marketing dalam Meningkatkan Kepuasan dan Loyalitas pada Lembaga Keuangan Mikro Syari'ah. Jurnal Ilmu Syari'ah dan Hukum, 49(2), 357-385. Available http:/ / www.google.com./ accessed.

Saputra, M. H. (2014). Masa Depan Penerapan Strategi Relationship Marketing Pada Industri Jasa Perbankan. Jurnal Manajemen dan Bisnis SEGMEN,10(1). Available at: http:/ / ejournal.umpwr.ac.id/index.php/segm en/article/view/1059.

Sin, L. Y. M. et al. (2005). Relationship Marketing Orientation: Scale Development And CrossCultural Validation. Journal of Business Research, 58(2), 185-194. doi: 10.1016/S01482963(02)00493-9.

Suparwata, Dewa Made, Budi Santoso, Sakti, D. P. B. (2017). Analisis Pengaruh Customer Relationship Marketing Terhadap Loyalitas Nasabah Pada PT. Bank Sinarmas Kantor Cabang Mataram. Jurnal Magister Manajemen Universitas Mataram, 6(1), 1-16.

Tjahyadi, R. A. (2010).Membangun Hubungan Jangka Panjang Pelanggan Melalui Relationship Marketing. Jurnal Manajemen Maranatha, 5(2), 3545.doi.org/10.28932/jmm.v5i2.231

Tjiptono, F. dan Gregorius Chandra. (2011).Service
Quality and Satisfaction. 3rd edition. Yogyakarta: Andi Publisher.

Wardayati, S. M. (2011).Implikasi Shariah Governance Terhadap Reputasi dan Kepercayaan Bank Syariah. Walisongo, 19(1), 124.

Yudiantoro, D. dan Setiawan, D. (2020). Pengaruh Shariah Relationship Marketing dan Kualitas Layanan Terhadap Kepuasan Pelanggan Serta Dampaknya Terhadap Word of Mouth Nasabah Bank Jatim Syari'ah Kediri. AnNisbah: Jurnal Ekonomi Syariah, 07(01), 273-301.

Yuliana et al. (2018). Pengaruh Relationship Marketing dan Keunggulan Produk Terhadap Kesetiaan. Jurnal Manajemen dan Inovasi, 9(2), 44-49.

Yusriadi. (2017). Pengaruh Relationship Marketing Terhadap Loyalitas Nasabah Pada PT. Bank Pembiayaan Rakyat Syariah (BPRS) Berkah Dana Fadhlillah Di Kabupaten Kampar Provinsi Riau. Jurnal Ilmiah Ekonomi dan Bisnis, 14(2), 115-120. 